\title{
Analyzing Irrigation Water Use Productivity and Irrigation Scheduling of Onion Farm Land in Serenta Irrigation Scheme, Northern Ethiopia
}

\author{
Gebre Gidey ${ }^{1, ~ *, ~ A z e n a w ~ K a l k a y ~}$ \\ ${ }^{1}$ Department of Natural Resource Management, Dambi Dollo University, Dambi Dollo, Ethiopia \\ ${ }^{2}$ Humera Agricultural Research Centre, Tigray, Ethiopia
}

Email address:

grbregidey09@gmail.com (G. Gidey)

*Corresponding author

\section{To cite this article:}

Gebre Gidey, Azenaw Kalkay. Analyzing Irrigation Water Use Productivity and Irrigation Scheduling of Onion Farm Land in Serenta Irrigation Scheme, Northern Ethiopia. International Journal of Applied Agricultural Sciences. Vol. 7, No. 5, 2021, pp. $213-218$. doi: $10.11648 /$ j.ijaas.20210705.11

Received: August 6, 2021; Accepted: September 26, 2021; Published: October 5, 2021

\begin{abstract}
Farmers in Serenta irrigation scheme have been irrigating their plots without considering the crop water requirement. This has resulted high loose of water and low water use productivity. This indicates that, the irrigation scheme needs scientific analyzing of water use productivity and irrigation scheduling to proper use of the water for more beneficial impacts. Therefore, the present study was conducted to analyze the water use productivity and irrigation scheduling in Serenta irrigation scheme, Northern Ethiopia. To evaluate the irrigation water use productivity, four farmers' fields covered with single crop onion from each position (head, middle and tail-end) water users of the irrigation scheme were selected. To determine the amount of water applied by the irrigators to the fields, Parshall flumes were installed at the entrance of test plots and the total yields obtained from each of the selected fields were collected directly from the fields. The results from the water use productivity analysis revealed that, the average water use productivity was found to be $1.3 \mathrm{~kg} / \mathrm{m}^{3}, 1.8 \mathrm{~kg} / \mathrm{m}^{3}$ and $2.1 \mathrm{~kg} / \mathrm{m}^{3}$ for the head, middle and tail-end users, respectively. The results indicated that, the tail-end users those who applied less water than the head and middle users, had the highest return per unit of water applied $\left(2.1 \mathrm{~kg} / \mathrm{m}^{3}\right)$. This might be due to the application of irrigation water nearest to gross irrigation water requirement. From the present study, it can be concluded that more water application means not more production. So, water use productivity can be improved by minimizing water losses due to over irrigation and applying water according to crop water requirement.
\end{abstract}

Keywords: Irrigation Scheduling, Irrigation Water Use Productivity, Onion Farm Land

\section{Introduction}

The most restrictive factor in dry areas agriculture is water, not land. Therefore, capitalize on water use productivity is a more appropriate tactic $[1,15]$. Water use productivity is identified as one of the key field level water use efficiency indicators, which is most important to individual farmer to evaluate whether the water has been used effectively or not [1].

According to Clement et al. [2], water use productivity defined as ratio between outputs derived from water use and the water volume applied (diverted) to the field. It is the efficiency with which yield is produced as a function of water used by the crop in the field [1].

Irrigation scheduling is the process or planning by determining the amount, frequency and duration of irrigations apply per irrigation in order to maintain healthy plant growth during the growing season [3]. As a result, it has significant effects on crop yield and farm productivity [4]. Proper irrigation scheduling is important to minimize water-logging problems, minimize crop water stress and maximize yields, and reduce energy, water and labor costs through less irrigation $[3,14]$.

Studies show that farmers, who practice poor water application techniques, obtain low onion productivity with a maximum loss of water [1]. Therefore, proper irrigation 
water application techniques are required to improve water productivity in water limited areas like Northern Ethiopia.

Farmers in Serenta irrigation scheme have been irrigating their plots without considering the crop water requirement. This has resulted high loose of water and low water use productivity [4]. This indicates that, the irrigation scheme needs scientific analyzing of water use productivity and irrigation scheduling to proper use of the water for more beneficial impacts. However, there are no researches carried out to validate the irrigation water use productivity and irrigation scheduling of onion farm land in Serenta irrigation scheme, northern Ethiopia.

Therefore, the present study was conducted to analyze the water use productivity and irrigation scheduling in Serenta irrigation scheme, Northern Ethiopia. Consequently, the present study will improve farmers' water use productivity in Serenta irrigation scheme by the advisable irrigation scheduling. And, it could serve as a base line for irrigation experts, researchers and policy makers' concerning irrigation water use productivity.

\section{Materials and Methods}

\subsection{Description of the Study Area}

Serenta irrigation scheme is found in North Western zone of Tigray regional State, Northern Ethiopia. It lies between latitude of $13^{\circ} 36^{\prime} 29^{\prime \prime}-13^{\circ} 34^{\prime} 18^{\prime \prime} \mathrm{N}$ and $38^{\circ} 09^{\prime} 45^{\prime \prime}-38^{\circ}$ 10'44" E longitude (Figure 1).

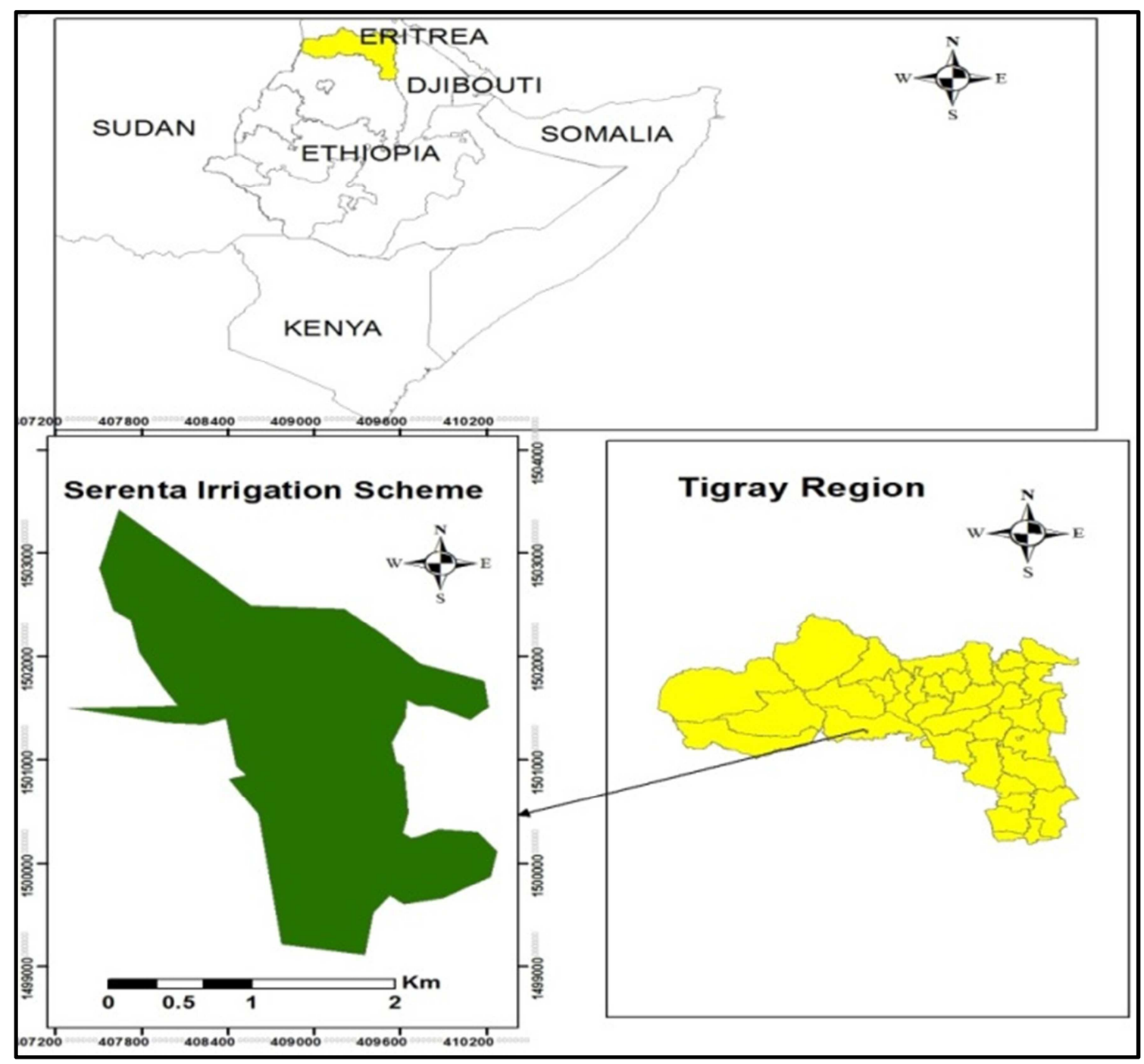

Figure 1. Location of the study area.

The study area is mainly hot semi-arid, with mean maximum $33.3^{\circ} \mathrm{C}$ and minimum $18.4^{\circ} \mathrm{C}$ temperature, and the annual average rainfall is $811.81 \mathrm{~mm}$. Summer is the longest rainy season which starts early of May and ends in October [5]. Rainy pattern is a monsoon model with a distinct peak in the period of June- September (Figure 2).
The main rock units found in the watershed area are basaltic, and the predominant soil in the watershed is clay.

The scheme has a total command area of 520 ha with total beneficiary of 800 (420 adults, 231 young and 150 females), out of which only 382 ha in 2016/17 and 394 ha in 2017/18 were irrigated [5]. Almost all of the farmers in the irrigation 
scheme irrigate vegetable crops (onion and tomato), and maize and pepper as major irrigated crops. Of all, onion is the dominant irrigated crop in this irrigation scheme.

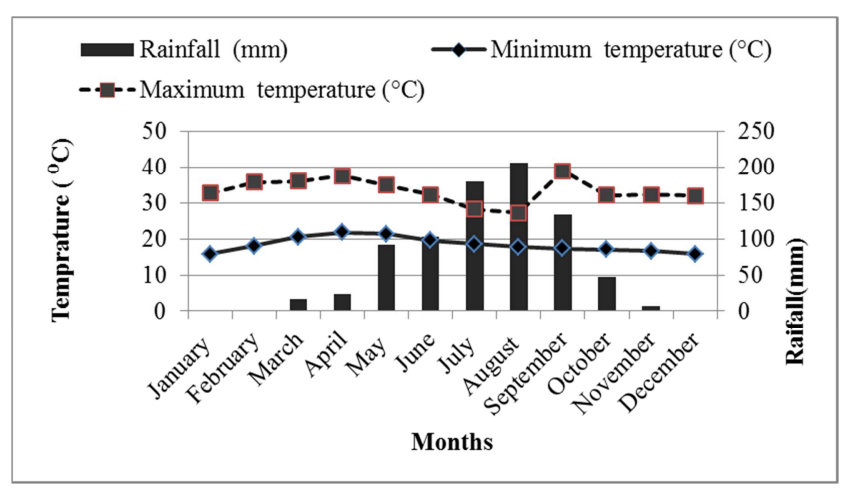

Figure 2. Climate of the study area.

\subsection{Sampling Procedure and Techniques}

To evaluate irrigation water use productivity interms of water applied depth, four farmers' fields covered with single crop onion (Red Bombay) from each position (head, middle and tail-end) water users of the irrigation scheme with equal size ( $0.25 \mathrm{ha})$ land and similar in soils, furrows lay out and other management practices (such as weeding and insect protections, and fertilizer application) were selected using systematic sampling method.

\subsection{Data Collection Methods}

\subsubsection{Measurement of Water Applied Depth (WAD) to Fields}

To determine the amount of water applied by the irrigators to the fields, Parshall flumes ( 3 inch) were installed at the entrance of test plots. Water applied depth to every plot was measured at each irrigation interval of all growth stages (initial, development, mid-season and late) of the crop (onion).

\subsubsection{Yield Collection}

The total yields (Bulbs) obtained from each of the selected fields (twelve plots) were collected with willingness and collaboration of the farmers.

\subsubsection{Climate Data Collection}

To analyze the crop water requirement of the study area (input for the CropWat software program), average climatic data from May-tsebri meteorological station, $5 \mathrm{~km}$ far from the study area were collected (Table 1).

Table 1. Averaged climatic data of the study area (Maytsebri station) and computed ETo.

\begin{tabular}{|c|c|c|c|c|c|c|c|c|}
\hline \multirow{3}{*}{ Month } & Minimum & Maximum & Relative & Wind & Sun shine & Solar Rad. & ETo & Rain fall \\
\hline & Temperature & Temperature & Humidity & Speed & hours & (MJ/m2/d) & $(\mathrm{mm} / \mathrm{day}$ & $(\mathrm{mm})$ \\
\hline & $\left({ }^{\circ} \mathrm{C}\right)$ & $\left({ }^{\circ} \mathrm{C}\right)$ & $(\%)$ & (km/day) & (hrs.) & & & \\
\hline January & 15.8 & 32.7 & 36 & 80 & 10.1 & 21.2 & 4.2 & 1.02 \\
\hline February & 18 & 35.7 & 30 & 104 & 10.6 & 23.5 & 5.25 & 1.78 \\
\hline March & 20.5 & 36 & 28 & 125 & 9.8 & 23.9 & 5.96 & 16.43 \\
\hline April & 21.8 & 37.5 & 29 & 130 & 10.3 & 25.4 & 6.55 & 23.1 \\
\hline May & 21.4 & 34.9 & 38 & 130 & 9.3 & 23.6 & 6.11 & 92.32 \\
\hline June & 19.6 & 32.2 & 52 & 121 & 9 & 22.8 & 5.46 & 102.83 \\
\hline July & 18.6 & 28.2 & 70 & 95 & 7.1 & 20.1 & 4.31 & 180.14 \\
\hline August & 17.7 & 27.2 & 79 & 104 & 7 & 20.1 & 3.95 & 206.22 \\
\hline September & 17.4 & 38.9 & 72 & 82 & 8 & 21.3 & 5.04 & 133.79 \\
\hline October & 17 & 32.1 & 51 & 77 & 9.7 & 22.6 & 4.72 & 47.27 \\
\hline November & 16.6 & 32.3 & 41 & 79 & 9.7 & 20.9 & 4.27 & 6.58 \\
\hline December & 15.8 & 31.9 & 39 & 101 & 9.8 & 20.1 & 4.28 & 0.33 \\
\hline Mean & 18.4 & 33.3 & 47 & 102 & 9.2 & 22.1 & 5.01 & - \\
\hline Total & $\ldots$ & _ & $\ldots$ & $\ldots$ & _ & _ & $\ldots$ & 811.81 \\
\hline
\end{tabular}

\subsection{Data Analysis Technique}

\subsubsection{Water Use Productivity (WUP) Analysis}

After determining the water applied depth at all growth stages of the crop and collected the total yield of the crop from the selected fields, the water use productivity in terms of water applied depth was determined using Equation 1 [6]:

$$
\text { WUP }\left(\mathrm{kg} / \mathrm{m}^{3}\right)=\text { Yield }(\mathrm{kg} / \mathrm{ha})
$$

Water applied volume $\left(\mathrm{m}^{3} / \mathrm{ha}\right)$

\subsubsection{Determination of Crop Water Requirement and Irrigation Scheduling}

Determination of crop water requirements is needed to know how much of the applied irrigation water is consumed by the crop [7].

Using the ten years mean climatic data of the study area, the crop water requirement, irrigation water requirement and irrigation scheduling of the selected irrigated crop (onion) at field level were determined by CROPWAT 8.0. Software.

Crop water requirements (ETc) over the growing seasons are determined from ETo and crop coefficient (Kc), and calculated as proposed by Allen et al. [8]. 


\section{$\mathrm{ETc}=\mathrm{Kc} * \mathrm{ETo}$}

Where: ETc is crop evapotranspiration, $\mathrm{Kc}$ is crop coefficient, and ETo is reference evapotranspiration.

\subsubsection{Statistical Analysis}

The water use productivity in terms of water applied depth across the positions/locations (head, middle and tail-end users) was compared statistically using one way-ANOVA.

\section{Results and Discussions}

\subsection{Water Applied Depth (WAD) at Growth Stages of Onion}

Understanding water application depth, which is the amount of water applied to field in irrigation event, is important indicator for evaluation of water use productivity in the irrigation scheme [9]. In this study, the total amount of water applied in full growing season to each fields were $1003.03 \mathrm{~mm}$, $862.7 \mathrm{~mm}$ and $665.6 \mathrm{~mm}$ in head, middle and tail-end users, respectively in the irrigation season. And, as it is indicated in Table 2, the head users applied more water than middle and tail users, and the middle users applied more water than the tail-end users per irrigation event. This indicated that there was a water application difference across positions.

The result from the one way- ANOVA analysis revealed that, statistically there was significant $(\mathrm{p}=0.02)$ variation at $5 \%$ significance level on water application depth across the positions (head, middle and tail-end users).

Table 2. Water applied depth at onion growth stages.

\begin{tabular}{lllll}
\hline Location & Crop growth stages & Average water applied $(\mathbf{m m})$ & No. of irrigation events (Days) & Total water applied depth (mm) \\
\hline Head & Initial & 67.5 & 2 & 135 \\
& Developmental & 80 & 5 & 400 \\
& Mid & 82.3 & 5 & 411.5 \\
& Late & 56.53 & 1 & 56.53 \\
& Mean & 71.53 & - & - \\
& Total & & 2 & 1003.03 \\
& Initial & 57.4 & 4 & 302.8 \\
& Developmental & 75.7 & 5 & 394 \\
& Mid & 78.8 & 1 & 51.1 \\
& Late & 51.1 & - & - \\
Tail-end & Mean & 65.75 & 2 & 862.7 \\
& Total & & 4 & 99.8 \\
& Initial & 49.9 & 4 & 255.2 \\
& Developmental & 63.8 & 1 & 261.6 \\
& Mid & 65.4 & & 49 \\
& Late & 49 & & - \\
& Mean & 57 & & 665.6 \\
\hline
\end{tabular}

\subsection{Yield of the Selected Plots}

The average yield production of the selected fields was found to be $8170 \mathrm{~kg} / \mathrm{ha}, 9671 \mathrm{~kg} / \mathrm{ha}$ and $8808 \mathrm{~kg} / \mathrm{ha}$ for the head, middle and tail-end users, respectively (Table 3 ). When comparing the three locations (head, middle and tail-end), in terms of yield productivity, the result indicated that, the middle users had the highest yield production, next the tail - end users. Regardless of the high water application in the head users they scored low yield production (Table 3).

Table 3. Total averaged yields of the selected plots.

\begin{tabular}{llll}
\hline Location & Farm area (ha) & Bulbs (Kg) & Bulbs (Kg/ha) \\
\hline Head & 0.25 & 2043 & 8170 \\
Middle & 0.25 & 2418 & 9671 \\
Tail-end & 0.25 & 2206 & 8808 \\
\hline
\end{tabular}

Table 4. Crop and irrigation water requirement of onion (CropWat output).

\begin{tabular}{|c|c|c|c|c|c|c|}
\hline \multirow{2}{*}{ Month } & \multirow{2}{*}{ Decade } & \multirow{2}{*}{ Stage of crop } & \multirow{2}{*}{ Ke } & ETc & \multirow{2}{*}{$\begin{array}{l}\text { ETc. } \\
\text { mm/decade }\end{array}$} & \multirow{2}{*}{$\begin{array}{l}\text { IR. } \\
\text { mm/ decade. }\end{array}$} \\
\hline & & & & mm/day & & \\
\hline Nov & 2 & Initial & 0.7 & 2.99 & 26.9 & 26.9 \\
\hline Nov & 3 & Initial & 0.7 & 2.99 & 29.9 & 29.9 \\
\hline Dec & 1 & Developmental & 0.75 & 3.22 & 32.2 & 32.2 \\
\hline Dec & 2 & Developmental & 0.87 & 3.71 & 37.1 & 37.1 \\
\hline Dec & 3 & Developmental & 0.99 & 4.21 & 46.3 & 46.3 \\
\hline Jan & 1 & Mid-season & 1.05 & 4.35 & 43.5 & 43.5 \\
\hline Jan & 2 & Mid-season & 1.05 & 4.29 & 42.9 & 42.9 \\
\hline Jan & 3 & Late-season & 1.05 & 4.68 & 51.5 & 51.5 \\
\hline Feb & 1 & Late-season & 1.01 & 4.92 & 49.2 & 49.2 \\
\hline Feb & 2 & Late-season & 0.96 & 5.04 & 20.2 & 20.2 \\
\hline Total & & & & & 379.7 & 379.7 \\
\hline
\end{tabular}

Kc- crop coefficient, ETc- crop evapotranspiration, and IR - irrigation requirement 


\subsection{Crop Water Requirement and Irrigation Scheduling of Onion}

\subsubsection{Crop and Irrigation Water Requirement}

Understanding seasonal crop and irrigation water requirements are important for planning cultivation of irrigated crops [10]. The crop and irrigation water requirement of the major dominated crop (onion) grown in the irrigation scheme during the study period as estimated by the CropWat- model, is indicated in Table 4. Since there was no rainfall during the study period, the crop and the irrigation water requirements were equal, $379.7 \mathrm{~mm}$.

The result indicated that the crop had the highest crop water requirement (ETc) during its late season stage (120.9mm) followed by the developmental stage $(115.6 \mathrm{~mm})$, mid-season $(86.4 \mathrm{~mm})$ and initial stage $(56.8 \mathrm{~mm})$ (Table 4$)$. This result reflects that this specific crop in the study requires high amount of water even during the last stage (late-season) for good yield production. Similarly, result reported by Yusuf [11] in Batu Degaga irrigation scheme (Western Ethiopia) indicated that onion crop requires high amount of water even in the late stage growing season of the crop.

\subsubsection{Irrigation Scheduling}

Irrigation scheduling is important to irrigators; to apply the exact amount of water and to use the irrigation water efficiently [12]. At the present study, the irrigation scheduling was calculated by taking the farmers application efficiency and irrigation interval practices in to consideration. The field application efficiency was $57 \%$, which was the average (scheme level) application efficiency practiced by farmers, and the timing of irrigation was fixed interval per stage (Table 5).

The application of the water has to refill to field capacity level, and the scheduling efficiency was $100 \%$. As it indicated in Table 5 the gross irrigation requirements (GIR) was estimated as $620.2 \mathrm{~mm}$ in full growing season of the crop. Therefore, for improving irrigation practice, only required amount of water is $620.2 \mathrm{~mm}$ per growing season of the crop.

Table 5. Irrigation scheduling of onion (CropWat output).

\begin{tabular}{|c|c|c|c|c|c|c|c|c|c|c|}
\hline \multicolumn{3}{|c|}{$\begin{array}{l}\text { Timing: irrigated at fixed } \\
\text { interval per stage }\end{array}$} & \multicolumn{4}{|c|}{ Application: Refill soil to field capacity } & \multirow{2}{*}{$\begin{array}{l}\text { Field efficiency: } \\
57 \% \\
\text { Net Irr. Mm } \\
\end{array}$} & \multicolumn{3}{|c|}{ Scheduling efficiency: $100 \%$} \\
\hline Date & Day & Stage & Rain Mm & Ks Frac. & Eta\% & Depl.\% & & Deficit Mm & Loss Mm & GIR. Mm \\
\hline 18-Nov & 7 & Initial & 0 & 1 & 100 & 35 & 20.9 & 0 & 0 & 36.7 \\
\hline 25-Nov & 14 & Initial & 0 & 1 & 100 & 30 & 20.9 & 0 & 0 & 36.7 \\
\hline 2-Dec & 21 & Dev'tal & 0 & 1 & 100 & 27 & 21.4 & 0 & 0 & 37.5 \\
\hline 8-Dec & 27 & Dev'tal & 0 & 1 & 100 & 22 & 19.3 & 0 & 0 & 33.9 \\
\hline 14-Dec & 33 & Dev'tal & 0 & 1 & 100 & 22 & 21.3 & 0 & 0 & 37.4 \\
\hline 26-Dec & 45 & Dev'tal & 0 & 1 & 100 & 22 & 25.2 & 0 & 0 & 44.3 \\
\hline 1-Jan & 51 & Mid & 0 & 1 & 100 & 21 & 25.4 & 0 & 0 & 44.5 \\
\hline 7-Jan & 57 & Mid & 0 & 1 & 100 & 22 & 26.1 & 0 & 0 & 45.8 \\
\hline 13-Jan & 63 & Mid & 0 & 1 & 100 & 22 & 25.9 & 0 & 0 & 45.5 \\
\hline 19-Jan & 69 & Mid & 0 & 1 & 100 & 21 & 25.7 & 0 & 0 & 45.1 \\
\hline 25-Jan & 75 & Mid & 0 & 1 & 100 & 23 & 27.7 & 0 & 0 & 48.6 \\
\hline 9-Feb & 90 & End & 0 & 0.85 & 98 & 59 & 71.3 & 0 & 0 & 125.1 \\
\hline Total & & & & & & & & & & 620.2 \\
\hline
\end{tabular}

GIR - Gross Irrigation Requirements

\subsection{Comparison Between Actual Farmers' Water Applied Depth and Computed Crop Water Requirement}

As calculated by the CropWat software program, the water requirement of the onion crop per irrigation season in the study area was $620.2 \mathrm{~mm}$ (Table 5). This value can be used for the whole farmers' fields (head, middle and tailend water users) to compare with actual water applied depth in growing season of the crop. The total amount of water applied in full growing season to each field's were $1003.03 \mathrm{~mm}, 862.7 \mathrm{~mm}$ and $665.6 \mathrm{~mm}$ in head, middle and tail-end users, respectively in the irrigation season (Table 2).

The entire water user locations were found to be irrigated their plots above the optimum value obtained from the program. This showed that the irrigators had applied more water than the required which implied that, the amount of water applied in each irrigation events depends on the personal observation of individual farmers, not based on the required depth. This leads to low water use productivity of irrigation system [8].

\subsection{Water Use Productivity (WUP) in Terms of Water Applied Depth}

The water use productivity was found to be $1.3 \mathrm{~kg} / \mathrm{m}^{3}$, $1.8 \mathrm{~kg} / \mathrm{m}^{3}$ and $2.1 \mathrm{~kg} / \mathrm{m}^{3}$ for the head, middle and tail-end users, respectively (Figure 3 ).

The results indicated that, the tail-end users those who applied less water than the head and middle users, had the highest return per unit of water applied $\left(2.1 \mathrm{~kg} / \mathrm{m}^{3}\right)$. This might be due to the application of irrigation water nearest to gross irrigation water requirement [13]. This was $665.6 \mathrm{~mm}$ in full growing season of the crop (onion) which was somewhat nearest to the gross irrigation water requirement 
(620.2 $\mathrm{mm})$ as compare to the others (head and middle users). In line with this, Worku [13] found high WUP $\left(2.03 \mathrm{Kg} / \mathrm{m}^{3}\right)$ in the tail users than the head and middle users in Midhegdu irrigation scheme (South Western Ethiopia).

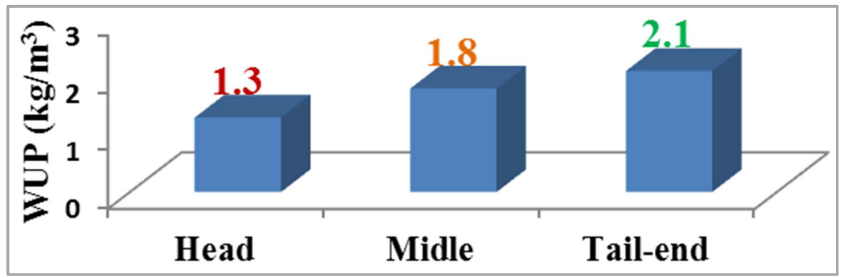

Figure 3. Water use productivity (WUP) in terms of water applied volume across locations.

\section{Conclusion and Recommendations}

\subsection{Conclusion}

From the result of water use productivity analysis, nevertheless of the water application depth, the highest value was obtained at the tail-enders followed by the middle and head users. This was because of somewhat efficient water application in the tail-end users. It was near to gross irrigation requirement.

From the present study, it can be concluded that more water application means not more production. So, water use productivity can be improved by minimizing water losses due to over irrigation and applying water according to crop water requirement.

In water scarcity areas like Northern Ethiopia, water use productivity improvement through proper irrigation scheduling is necessary. Irrigation scheduling helps to apply water at a right time and right amount to specific crops.

\subsection{Recommendations}

1. The water use productivity can be improve by minimizing water losses and applying water according to crop water requirement.

2. Qualified development agents with irrigation agronomy background should be assigned in the scheme to develop irrigation agronomy manuals such as simplified crop water requirements for the beneficiaries.

3. To improve water use productivity, farmers should be given training on irrigation water use and management.

\section{References}

[1] Molden D., Oweis T., Steduto P., Bindraban P., Hanjra H. A., Kijne J. Improving agricultural water productivity: Between optimism and caution. Agr. Wat. Manage, 2010, Vol. 97 (4): 528-535.
[2] Clement, F., Haileslassie, A., Ishaq, S., Bluemmel, M., Murty, M. R., Samad, M., \& Khan, M. A. Enhancing water productivity for poverty alleviation: Role of capitals and institutions in the Ganga Basin. Experimental Agriculture, 2011, 47 (S1), 133-151.

[3] FAO. Crop Yield Response to Water. FAO Irrigation and Drainage Paper, 2012, No. 66. FAO, Rome.

[4] FAO. Guidelines for Designing and Evaluating Surface Irrigation System: Irrigation and Drainage Paper, 1989, No. 45. FAO, Rome.

[5] WTARDO (Wereda Tselemti Agriculture and Rural Development Office). Annual Report, Maytsebri, Tigray, Ethiopia, 2018.

[6] Araya, A., Stroosnijder, L., Girmay, G., \& Keesstra, S. D. Crop coefficient, yield response to water stress and water productivity of teff (Eragrostis teff). Agricultural water management, 2011, 98 (5), 775-783.

[7] FAO. Irrigation Scheduling: From theory to practice. Water Reports, 8. FAO, Rome, 1996.

[8] Allen, R. G., Pereira, L. S., Raes, D., \& Smith, M. Crop evapotranspiration-Guidelines for computing crop water requirements. FAO Irrigation and drainage paper 56. FAO, Rome, 1998, 300 (9).

[9] Abernethy, C. L. Performance measurement in canal water management: a discussion. Overseas Development Institute (ODI), 1986.

[10] Adeniran, K. A., Amodu, M. F., Amodu, M. O., \& Adeniji, F. A. Water requirements of some selected crops in Kampe dam irrigation project. Australian Journal of Agricultural Engineering, 2010, 1 (4), 119.

[11] Yusuf, K. Assessment of small scale irrigation using comparative performance indicators on two selected schemes in upper Awash River valley, M.Sc. Thesis, Alemaya University. Alemaya, Ethiopia, 2004.

[12] James L. G. (1988). Principles of Farm Irrigation System Design. John Wiley \& Sons, Inc. New York, 1988, 543p.

[13] Worku, N. Technical Performance evaluation of Midhegdu small scale irrigation scheme in west Hararge zone, Oromia region, Ethiopia. M.Sc. thesis, Haramaya University. Haramaya, Ethiopia, 2013.

[14] Gebre G. "Impact of Small Scale Irrigation Development on Farmers' Livelihood Improvement in Ethiopia: A Review." Journal of Resources Development and Management 62 (2020): 10-18.

[15] Gebre G. "Performance Evaluation of Organizational Arrangement in Irrigation Water Management at Serenta Irrigation Scheme, Northern Ethiopia." Irrigat DrainageSyEng10 (2021): 273. 